\title{
Correction to: Triheptanoin in the management of long-chain fatty acid oxidation disorders: a profile of its use
}

\author{
Esther S. Kim ${ }^{1}$. Susan J. Keam ${ }^{1}$ (1)
}

Published online: 21 April 2021

(c) Springer Nature 2021

\section{Correction to: Drugs \& Therapy Perspectives https://doi.org/10.1007/s40267-021-00816-3}

The article Triheptanoin in the management of long-chain fatty acid oxidation disorders: a profile of its use, written by Esther S. Kim and Susan J. Keam, was originally published electronically in SpringerLink on 20 March 2021 without open access. After publication online, Ultragenyx Pharmaceutical Inc. requested that the article be Open Choice to make the article an open access publication. Post-publication open access was funded by Ultragenyx Pharmaceutical Inc. This article is licensed under a Creative Commons Attribution-NonCommercial 4.0 International License, which permits any non-commercial use, sharing, adaptation, distribution and reproduction in any medium or format, as long as you give appropriate credit to the original author(s) and the source, provide a link to the Creative Commons licence, and indicate if changes were made. The images or other third party material in this article are included in the article's Creative Commons licence, unless indicated otherwise in a credit line to the material. If material is not included in the article's Creative Commons licence and your intended use is not permitted by statutory regulation or exceeds the permitted use, you will need to obtain permission directly from the copyright holder. To view a copy of this licence, visit http://creativecommons.org/licenses/by-nc/4.0/.

The original article can be found online at https://doi.org/10.1007/ s40267-021-00816-3.

Susan J. Keam

demail@springer.com

1 Springer Nature, Private Bag 65901, Mairangi Bay, Auckland 0754, New Zealand
The original article has been corrected.

Open Access This article is licensed under a Creative Commons Attribution-NonCommercial 4.0 International License, which permits any non-commercial use, sharing, adaptation, distribution and reproduction in any medium or format, as long as you give appropriate credit to the original author(s) and the source, provide a link to the Creative Commons licence, and indicate if changes were made. The images or other third party material in this article are included in the article's Creative Commons licence, unless indicated otherwise in a credit line to the material. If material is not included in the article's Creative Commons licence and your intended use is not permitted by statutory regulation or exceeds the permitted use, you will need to obtain permission directly from the copyright holder. To view a copy of this licence, visit http://creativecommons.org/licenses/by-nc/4.0/. 